\title{
Effect of Tax Avoidance and Tax Evasion on Personal Income Tax Administration in Nigeria
}

\author{
Adebisi, J. F, Ph.D ${ }^{1}$ and Gbegi, D.O ${ }^{2}$ \\ ${ }^{1}$ Director General, Nigerian College of Accountancy, Jos, Nigeria \\ ${ }^{2}$ Department of Accounting, Kogi State University, Anyigba, Nigeria
}

\begin{abstract}
The study examines the effect of tax avoidance and tax evasion on personal income tax administration in Nigeria. Tax evasion and tax avoidance, a problem which seems to have defied solution, had been deviled the tax system right from colonial times. While some had blamed the situation on tax authorities for not living up to expectation with regards to tax administration, others attribute it to the unpatriotic attitude of tax payers. It was in this light of contending position that the researcher carryout a survey in Nigeria with particular reference to Federal Inland Revenue Service Abuja. The sample size was derived statistically using Yaro Yamani formula. The sample size consists of three hundred and five (305) employees of Federal Inland Revenue Service Abuja. The study utilizes primary and secondary data. Tables and percentages were used for the analysis. The Analysis of Variance (ANOVA) was used to test the hypotheses. The research findings disclose that enlightenment and adequate utilization of tax revenue on public goods will discourage tax avoidance and tax evasion, high tax rates encourage tax avoidance and tax evasion, personal income tax generation has not being impressive and personal income tax rates are too high. The researcher therefore concluded that there is a direct and positive relationship between tax avoidance, tax evasion, tax rates and personal income tax administration in Nigeria. Hence recommended that tax officials should be constantly trained and retrained on the job, a deliberate and more aggressive public enlightenment campaign should be embarked upon by government and the reduction in tax rates for the poor.
\end{abstract}

Key Words: Tax avoidance, tax evasion, personal income tax, effect, administration

\section{Background of the Study}

The desire to uplift one's society is the first desire of every patriotic citizen (Allingham \& Sandmo, 1972). Tax payment is a demonstration of such a desire. The payment of tax is a civic duty and an imposed contribution by government on her subjects and companies to enable her finance or run public utilities and perform other social responsibilities. Taxes, thus, constitutes the principal source of government revenue.

However, one of the greatest problems facing Nigerian Tax System as well as Africa is the problem of tax evasion and tax avoidance. While tax evasion is the willful and deliberate violation of the law in order to escape payment of tax which is unquestionably imposed by law of the tax jurisdiction, tax avoidance is the active means by which the taxpayer seeks to reduce or remove altogether his liability to tax without actually breaking the law.

These "Twin devils" have created a great gulf between actual and potential revenue. The government has for the umpteenth time complained of the widespread incidence of tax avoidance and evasion in the state as companies and other taxable persons employ various tax avoidance devices to escape or minimize their taxes or deliberately employ fraudulent ways and means of evading tax altogether sometimes with the active connivance of the tax officials. As pointed out by Rynoids (1963), since tax is a principal source of government revenue, if persons are able to escape by legal or illegal means the tax to which they should logically be subject under the general scope of the tax, the theoretical equity of the tax to a large measure is lost. Tax evasion and avoidance no doubt deny any government the tax revenue due to her, which results in a gap between the potential and actual tax collections. This study is aimed at bridging this gap.

\section{Statement of the Problem}

Although tax evasion and avoidance are problems that face every tax system, the Nigerian situation seems unique when viewed against the scale of corrupt practices prevalent in Nigeria. Under direct personal taxation as practiced in Nigeria, the major problem lies in the collection of the taxes especially from the self-employed such as the businessmen, 
contractors, professional practitioners like lawyers, doctors, accountants, architects and traders in shops among others. As observed by Ayua (1999) these persons blatantly refuse to pay tax by reporting losses every year. According to him, many of these professionals live a lifestyle inconsistent with reported income, which is usually unrealistically low for the nature of their businesses. Civil Servants and their salaried workers are the only class of people that actually pay tax in Nigeria. However, even among the salaried workers, he added, many have turned the statutory personal allowances and relief into a fertile ground for tax evasion. Almost all Nigerian taxpayers are married with four children! Similarly, despite the tax provision meant to plug loopholes through which taxable persons can minimize tax liability the selfemployed persons employ all kinds of avoidance schemes to minimize or escape tax liability and makes you wonder whether there are still any tax officials working in that capacity. Such scenarios, no doubt, say a lot about tax administration system in Nigeria both in its design and in the disposition of some taxpayers towards taxation. While it immediately presupposes that there are legal framework put in place to punish tax evaders it perhaps raises a poser on the efficiency and effectiveness of tax laws and tax administration in Nigeria. Some state governments in an effort towards solving this problem had even gone to the extent of engaging the services of tax consultants. This government effort, notwithstanding, the problem of tax evasion and avoidance still persists (Alabi, 2001 as cited by Ayodele,2006). There is no doubt that revenue due any government will be reduced by the unpatriotic act of tax evaders thereby affecting economic growth.

\section{Objectives of the Study}

The main objective of the study is to find out why people evade and avoid taxes and suggest ways of minimizing the practice in Nigeria. Other specific objectives are as follows:

1. To determine the effect of tax evasion and avoidance on personal income tax generation in Nigeria.

2. To examine the relationship between the tax rates, tax evasion and tax avoidance.

\section{Hypotheses}

Ho: There is no significant relationship between tax avoidance tax evasion and the personal income tax administration in Nigeria.

Ho: there is no significant relationship between tax rates, tax avoidance and tax evasion.

\section{Empirical Review}

There is a clear cut difference between tax avoidance and tax evasion. One is legally accepted and the other is an offence (Skanda and Kumarasingam, 2002 as cited by James and Nobes, 2008). Tax avoidance is the legal utilization of the tax regime to one's own advantage, to reduce the amount of tax that is payable by means that are within the law. By contrast, tax evasion is the general term for efforts not to pay taxes by illegal means (Sharma and Dang 2011 as cited by Mohammed and Mohammed, 2012). It is also perceived that both tax avoidance and tax evasion are linked with shadow economy and Schneider and Enste (2000) as cited by Faseun (2001) reported that shadow economy is that economy in which people do not show their real income and taxable income that they have earned through legal activities including batter and monitory activities in order to avoid paying tax. According to Muhammed and Muhammed (2012), government has protested against these two above mentioned evils for number of times but corporations and all other persons whose income is taxable, they make use of tax avoidance strategies to get away or curtail the taxes or they willfully employ fake techniques with the support of tax officials to evade the total tax.

Lefebvre et aL (2011) conducted study in Netherlands, France and Belgium (Flanders and Wallonia) while examining the behavior of people. He compared the behavior of people regarding welfare dodging and tax evasion. Results indicated that people adopt less evaded behavior in tax treatment than in welfare treatment; and people evade more tax in Netherlands and France but tax evasion is more in Flemish than Walloons. Liadiale et al. (2010) conducted study in Nigeria while examining relationship between personal income tax evasion and cultural factors like religiosity, trust in government, and legal enforcement. Study found positive impact on personal income tax of trust in government and legal enforcement. However, no significant relationship found between religious variables and tax evasion in Nigeria. Boylan and Sprinkle (2001) conducted study in which he tried to explore the behavioral of the determinants of tax evasion. He used experiment technique in order to acquire desired objectives such as to identify the factors that motivate the tax compliance and characteristics of noncompliant taxpayers. Pommerehne et al. (1994) conducted study in order to recognize the determinants of tax evasion. They used the presence of grievance in absolute terms in their study. Results indicated that as the sentiments of grievance increased in absolute terms, the level of tax evasion also increased and the level of tax moral 
belief decreased. Fisher et at (1989) also examined the behavior of taxpayers in order to explore the behavioral determinants of tax evasion. He used random survey technique in order to acquire desired objectives like to identify the factors that motivate the tax compliance and characteristics of noncompliant taxpayers.

Skinner and Slemrod (1985) conducted a study in order to investigate the determinants of tax evasion. In this study, only strict economic determinants proposed by seminal models were taken. Study found that considerable share of effective tax compliance cannot be explained by using these solely variables. Srinivasan (1973) also introduced seminal theoretical models and conducted study while exploring the determinants of tax evasion. In this study, he explained that the behavior of tax evasion was based on level of risk aversion, amount of penalty imposed, and probability of being audited. Likewise, study found an ambiguous relationship between marginal tax rate or income and tax evasion. Orewa (1957) conducted study and investigated the characteristics of tax evasion. Study found that high degree of inter-district mobility is the main reason of tax evasion on the part of taxpayers and argued that mobility of wage earners, salaried persons and self-employed persons with permanent and known addresses is an important factor of tax evasion because they keep themselves in movement from one place to another in order to earn legal money. He also found the reasons of partial evasion such as: resentment toward illiterate persons that present only their salaries arid wages as taxable income and traders maintain inadequate records.

The previous studies have done much in the area of tax evasion and avoidance but failed to cover the relationship between tax evasion and avoidance and personal income tax administration which this study will cover the gap.

\section{Personal Income Tax}

This is a tax levied on employment income and any other income received by individuals. Individuals here being those in paid employment and those in self- employment, i.e. those engaged in a trade, business, profession or vocation such as lawyers, accountants, doctors, traders in shops etc. The assessment and collection of this tax in Nigeria is regulated by the Personal Income Tax Act No. 104 LFN, 1993. It is this law that gives the necessary procedures and administrative powers to impose and collect taxes from persons, individuals, partnerships, executors, trustees Family or Communities Corporation sole or body of individuals. Personal
Income Tax is collected by the various state governments through the State Board of Internal Revenue (SBIR) from individuals resident in the tax territory. Taxes from certain categories of individual - members of the Armed Forces, the Nigeria Police, FCT residents, External Affairs Officials and nonresident individuals- are collected by the Federal Government via the Federal Board of Inland Revenue (FBIR).

By the provisions of the Approved list for Collection Decree (Decree No. 21 of 1998), the following taxes/levies are collectible by State Governments in Nigeria: 1. Personal Income Tax: (a) Pay-as-you-earn (PAYE), (b) Direct (Sell and government) Assessment (c) Withholding Tax (individuals only). 2. Capital Gains Tax (Individuals only) 3. Stamp Duties (instruments executed by individuals); 4. Pools Betting and Lotteries, Gaming, and casino Taxes; 5. Road Taxes; 6. Business premises registration and renewal levy: (i) Urban areas as defined by each state: maximum of $\$ 10$, 000.00 for registration and $\$ 5,000.00$ for renewal per annum, (ii). Rural areas: Registration: $\$ 2000$.O0; - Renewal: 1000.00 per annum. 7. Development Levy (individuals only) not more than $\$ 100.00$ per annum on each taxable individual; 8. Naming of street registration fee in state capitals; 9. Right of occupancy fees on land owned by the state government in urban areas of the state. 10. Market taxes where state finance is involved.

\section{Conceptual issues}

Tax avoidance arises in a situation where the taxpayer arranges his financial affairs in a way that would make him pay the least possible amount of tax without infringing the legal rules. In short it is a term used to denote those various devices which have been adopted with the aim of saving tax and thus sheltering the taxpayers' income from greater liability which would have been otherwise incurred (Kiabel, 2001). Ani et al (1978) had described tax avoidance as follows: the taxpayers knowing what the law is decide not to be caught by it, arranges his business in such a mariner as to escape tax liability partially or entirely. It is a lawful trick or manipulation to evade the payment of tax. The meaning of tax avoidance is vividly captured in the case involving Ayrshire Pullman Motor Services and David M. Ritchin Vs Commissioner of Inland Revenue when the Lord President Lord Clyde held that: No man in this country is under the smallest obligation moral or otherwise so to arrange his legal relations to his business or to his property as to enable the Inland Revenue to put the largest possible 
shovel into his stores. The Inland Revenue is not slow and quite rightly to take every advantage, which is open to it under the taxing statutes for the purpose of depleting the taxpayer's pocket And the taxpayer is in like manner entitled to be astute to prevent so far as he honestly can the depletion of his means by the Revenue.

Thus, it is clear that tax avoidance is legal or at least not illegal since one is mostly probably using the tax laws to limit his tax liability under the same laws. Examples of tax avoidance include: (i) Seeking professional advice; (ii)Reducing one's income by submitting claims for expenses in earning the income; (iii) Increasing the number of one's children (in Nigeria the maximum allowable is four); (iv) Taking additional life assurance policies. Tax avoidance is thus considered to be a matter of being sensible.

While the law regards tax avoidance as a legitimate game tax evasion is seen as immoral and illegal. Tax evasion is an outright dishonest action whereby the taxpayer endeavors to reduce his tax liability through the use of illegal means. According to Farayola (1987), tax evasion is the fraudulent, dishonest, intentional distortion or concealment of facts and figures with the intention of avoiding the payment of or reducing the amount of tax otherwise payable. Tax evasion is accomplished by deliberate act of omission or commission which in them constitutes criminal acts under the tax laws. These acts of omission or commission might include: (a) failure to pay tax e.g. withholding tax; (b) failure to submit returns; (c) omission or misstatement of items from returns; d) darning relief (in Personal Income Tax), for example, of children that do not exist; (e) understating income; (f) documenting fictitious transactions; (g) overstating expenses; (h) failure to answer queries.

The most common form of tax evasion in Nigeria is through failure to render tax returns to the Relevant Tax Authority. A tax evader may be charged to court for criminal offences with the consequent fines, penalties and at times imprisonment being levied on him for evading tax (Faseun 2001). And as observed by Sosanya (1981): Tax evading has become the favorite crime of the Nigerian, so popular that it makes armed robbery seem like minority interest. It has become so widespread that there now exists a cash economy of vast proportions over which the taxman has no control and which is growing at several times the rate of the national economy. No doubt, tax evasion and avoidance had robbed the Nigerian government of substantial tax revenue. According to the Nigerian Stock Exchange, 85 percent of corporate tax revenue in the country accrues from the 196 companies listed on the exchange compared to the 30,000 companies registered with the Corporate Affairs Commission. This is a serious indictment of the administrative machinery and capacity of the tax authorities in Nigeria.

\section{Causes of Tax Evasion and Tax Avoidance in Nigeria}

The causes of tax evasion and avoidance are universal, as they are applicable in any country that tax is imposed. Some are peculiar to different areas, however. In Nigeria some of these causes as identified by Onuigbo (1986) include:

\section{The Absence of a "Quid Pro Quo"}

The average human being abhors the payment of tax. $\mathrm{He}$ sees taxation as a discredited imposition and evidently obnoxious. This stems mainly from the absence of a "quid pro quo" i.e. something of value given in return by the Government) for the taxes paid. It is commonly argued, taxes should not be paid as the authority does not provide amenities which are in any way commensurate with the taxes paid. There is no guaranteed compensatory benefit.

\section{Inequitable Distribution of Amenities}

In many parts of Nigeria citizens are opposed to the payment of any form of taxes and rates on the ground that government had been unfair in the distribution of amenities and other good things of life. This thinking is often a root cause of most civil disturbances in parts of the country.

\section{Misuse or Mismanagement of Collections Made}

More often than not there are reports in the news media of how government functionaries misuse taxpayer's money. Evidences of wastage of public funds abound in the form of inflated contract prices, in unexecuted but paid contracts or in the criminal acts of using diverse methods and loopholes to exhaust funds voted for ministries and governmental departments before the financial year run out. The cumulative effect thereby produced is the resolve of many honest taxpayers never to pay theft due taxes again, or at most pay under compulsion.

\section{Remoteness of Taxpayers from the Government}

There is this common belief which most taxpayers have about the nature of government. The average Nigerian has an inborn bias or hatred against most 
government functionaries who in most cases live apart from the taxpayers. It hurts, most taxpayers would reason, for one to part with his hard earned resources for the upkeep of these (imagined) enemies. The creation of local government councils, which is supposed to bring government closer to the people, had not helped matters. As argues by Kiabel (2001), a solution to the problem probably lies in the proper education and orientation of the taxpayers towards government and its functionaries.

\section{Absence of Spirit of Civic Responsibility}

Most Nigerians probably due to illiteracy and ignorance fail to understand that they owe certain responsibilities to government, one of which is the payment of tax. Even when the government says it is poor they would rather argue that the government should print more money to solve her problems. This lack of spirit of civic responsibility amongst the majority of Nigerians is a major cause of tax evasion in Nigeria.

Some other authors have at one time or the other attributed the causes(s) of tax evasion and avoidance to various reasons. For example Orewa (1957) had earlier investigated the characteristics of evasion and found that complete evasion results from high degree of inter-district mobility on the part of the taxpayers. According to him, due to mobility, evasion is more pronounced on the part of self- employed taxpayers who move from compound to compound at frequent intervals than it is, with salary and wage earners with known and permanent address. He contended also that partial evasion may be due to inadequate accounting records maintained by traders, mistaken belief on the part of some illiterate taxpayers that only wages and salaries represent taxable income.

Kiabel (2001) has argued that some businessmen do not see any reason why they should pay tax irrespective of the fabulous profits made- This is the direct display of the spirit of unpatriotic: Such people take the stand that no matter the income or revenue that was acquired during the year nothing will be paid as tax or they may prepare their accounts in such a way that a loss will be reflected. Generally tax evasion which is illegal achieves the same goal as tax avoidance.

\section{Effects of Tax Evasion and Avoidance on Government Revenue}

Tax evasion and avoidance have adverse effect on government revenue. Tax avoidance generates investment distortion in the form of the purchase of assets exempted from tax or under-valued for tax purposes. Avoidance takes the form of investment in arts collection, emigration of persons and capital. And as observed by Toby (1983) the taxpayer indulges in evasion by resorting to various practices. These practices erode moral values and build up inflationary pressures. This point can be buttressed with the fact that because of the evasion of tax, individuals and companies have a lot of money at their disposal. Companies declare higher dividends and individuals have a high take home profit. This increase the quantity of money in circulation but without a corresponding increase in the goods and services. This then build up what is known as inflationary trends where large money chases few goods.

\section{Theoretical Framework}

\section{Theory of taxation}

According to Eftekhari, (2009) taxation has always been an issue for the government and taxpayers alike from the early years of civilization. The issue of taxation has generated a lot of controversy and severe political conflicts over time. According to its importance, several economic theories have been proposed to run an effective system. Taxes are generally classified under three different theories as given: ability to pay principle, benefit approach and equal distribution principle. However, in this paper is guided by the "ability to pay principle".

Ability-to-Pay Principle: As the name suggests, it says that the taxation should be levied according to an individual's ability to pay. It says that public expenditure should come from "him that hath" instead of "him that hath not". The principle originated from the sixteenth century, the ability-topay principle was scientifically extended by the Swiss philosopher Jean Jacques Rousseau (17121778), the French political economist Jean- Baptiste Say (1767-1832) and the English economist John Stuart Mill (1806-1873). This is indeed the basis of 'progressive tax,' as the tax rate increases by the increase of the taxable amount. This principle is indeed the most equitable tax system, and has been widely used in industrialized economics. The usual and most supported justification of ability to pay is on grounds of sacrifice. The payment of taxes is viewed as a deprivation to the taxpayer because he surrendered money to the government which he would have used for his own personal use. However, there is no solid approach for the measurement of the equity of sacrifice in this theory, as it can be measured in absolute, proportional or marginal terms. Thus, equal sacrifice can be measured as: (i) Each 
taxpayer surrenders the sane absolute degree of utility that s/he obtains from her/his income; (ii) Each sacrifice the same proportion of utility she/he obtains from her/his income; (iii) Each gives up the same utility for the last unit of income; respectively.

\section{Research Design}

The researcher adopts survey research design while carrying out the study. Both primary and secondary sources of data collection were used. Questionnaire was used to obtained information for primary source while text books, journals and internet were used for secondary source. The questionnaire was closedended with strongly agreed, agreed, disagreed and strongly disagreed responses. The questionnaire was administered on face to face to the employees of Federal Inland Revenue Service (FIRS) Abuja, Federal Capital Territory, Nigeria. The population for this study comprises of one thousand two hundred and ninety eight (1298) employees of Federal Inland Revenue service.

\section{Sample Size and Sample Techniques}

The research derived the sample size statistically by using Yaro Yamane (Abdullahi, 2012 as cited by Mohammed and Mohammed, 2012), as follows:

$\mathrm{n}=$

$$
\frac{\mathrm{N}}{1+\mathrm{n}(\mathrm{e})^{2}}
$$

Where $\mathrm{n}=$ Sample size

$$
\begin{aligned}
& \mathrm{N}=\text { Population } \\
& \mathrm{e}=\text { Level of significance }(0.05) \\
& \mathrm{n}=
\end{aligned}
$$

The sample size consists of three hundred and five (305) employees of Federal Inland Revenue Service.

\section{Method of Data Analysis}

Data collected were presented in table with simple percentage and the hypotheses were tested using the analysis of variance (ANOVA).

Model specification is the analysis of variance (ANOVA). As thus:

$$
\begin{aligned}
& \mathrm{SSB}=\mathrm{r} \sum(\mathrm{x} \ddot{j}-\mathrm{x})^{2}- \\
& \mathrm{SSW}=\sum \sum(\mathrm{xij}-\mathrm{x})^{2}
\end{aligned}
$$

Where: $\mathrm{SSB}=$ btw treatment sum of square

$\mathrm{SSW}=$ within treat sum of the square column mean

$\mathrm{Xij}=$ individual observation around their

$$
\begin{aligned}
& \mathrm{X}=\text { grand mean column } \\
& \mathrm{df}=\text { degree of freedom }(\mathrm{c}-1)(\mathrm{n}-1) \\
& \mathrm{c}=\text { number of column } \\
& \mathrm{N}=\text { number of observation } \\
& \mathrm{r}=\text { Number of row } \\
& \sum=\text { Summation } \\
& \text { Level of significance }(0.05)
\end{aligned}
$$

\section{Data Presentation, Analysis and Interpretation}

Data presented here are those collected from the field survey on the study. This would form the basis for the testing of the research hypotheses. Three hundred and five copies of questionnaire were administered and two hundred and eighty six were fully filled and returned.

From the Table 1, 196 respondents represent representing $69 \%$ of the total respondents strongly agree that enlightenment and adequate utilization of tax revenue on public goods will discourage tax avoidance and tax evasion, 56 respondents representation $20 \%$ of the total respondents agree with the above statement. While 9 respondents representing $3 \%$ said no idea. Apparently, 13 respondents representing $5 \%$ of the total respondents disagree with the above statement and 10 respondents representing $3 \%$ of the total respondents strongly disagree with the above statement.

Table 1. Enlightenment and adequate utilization of tax revenue on public goods will discourage tax avoidance and tax evasion.

\begin{tabular}{lcc}
\hline \multicolumn{1}{c}{ Options } & Frequency & Percentage (\%) \\
\hline Strongly agree & 198 & $69 \%$ \\
Agree & 56 & $20 \%$ \\
No Idea & 9 & $3 \%$ \\
Disagree & 13 & $5 \%$ \\
Strongly disagree & 10 & $3 \%$ \\
Total & 286 & $100 \%$ \\
\hline
\end{tabular}


From table 2, 158 respondents representing 55\% of the total respondents strongly agree that high tax rate encourages tax avoidance and tax evasions, 110 respondents representing $38 \%$ of the total respondents agree with the above statement While 2 respondents representing $1 \%$ said no idea whether high tax rate encourages tax avoidance and tax evasion or not. 12 respondents representing $4 \%$ of total respondents disagree that high tax rate encourages tax avoidance and evasion and 4 respondents representing $1 \%$ strongly disagree to the above statement.

Table 2: High tax rate encourages tax avoidance and tax evasion.

\begin{tabular}{lcc}
\hline \multicolumn{1}{c}{ Options } & Frequency & Percentage (\%) \\
\hline Strongly agree & 158 & $55 \%$ \\
Agree & 110 & $38 \%$ \\
No Idea & 2 & $1 \%$ \\
Disagree & 12 & $4 \%$ \\
Strongly disagree & 4 & $1 \%$ \\
Total & 286 & $100 \%$ \\
\hline
\end{tabular}

From table 3, 172 respondents representing $60 \%$ of the total respondents strongly agree that personal income tax generation has not being impressive, 80 respondents representing $27 \%$ of the total respondents agree with the above statement, while 4 respondents representing $1 \%$ said no idea whether personal income tax generation has not being impressive or not. 18 respondents representing $6 \%$ of the total respondent disagree that personal income tax generation has not being impressive and 12 respondents representing $4 \%$ strongly disagree to the above statement

Table 3. Personal income tax generation has not being impressive.

\begin{tabular}{lcc}
\hline \multicolumn{1}{c}{ Options } & Frequency & Percentage (\%) \\
\hline Strongly agree & 172 & $60 \%$ \\
Agree & 80 & $27 \%$ \\
No Idea & 4 & $1 \%$ \\
Disagree & 18 & $6 \%$ \\
Strongly disagree & 12 & $4 \%$ \\
Total & 286 & $100 \%$ \\
\hline
\end{tabular}

From table 4 above, 90 respondents representing $31 \%$ of the tota1 respondents strongly agree that personal income tax rate is too high, 140 respondents representing $49 \%$ of the total respondents agree with the above statement. While 6 respondents representing $2 \%$ said no idea whether personal income tax rate is too high or not. 37 respondents representing $13 \%$ of the total respondents disagree that personal income tax is too high and 13 respondents representing $5 \%$ strongly disagree to the above statement.

Table 4. Personal income tax rate is too high.

\begin{tabular}{lcc}
\hline \multicolumn{1}{c}{ Options } & Frequency & Percentage (\%) \\
\hline Strongly agree & 90 & $31 \%$ \\
Agree & 140 & $49 \%$ \\
No Idea & 6 & $2 \%$ \\
Disagree & 37 & $13 \%$ \\
Strongly disagree & 13 & $5 \%$ \\
Total & 286 & $100 \%$ \\
\hline
\end{tabular}




\section{Test of Hypotheses}

\section{Hypothesis 1: Decision Rule}

Using the ANOVA test in Table 5, we reject the null hypothesis and therefore accept the alternative hypothesis since $\mathrm{F}_{\text {cal }}$ is greater than $\mathrm{F}_{\mathrm{tab}}$. That is 156.1 $>5.32$ at 0.05 level of significance this means that there is significant relationship between tax avoidance, tax evasion and the personal income generation in Nigeria.

Table 5. ANOVA test statistics.

\begin{tabular}{lcccc}
\hline \multicolumn{1}{c}{ Source } & Ss & df & ms & F-ratio \\
\hline Between treatment & 44898.52 & 1 & 44898.52 & \\
& & & & 156.1 \\
Within treatment & 2301 & 8 & 287.625 & \\
Total & 47199.52 & 9 & & \\
\hline
\end{tabular}

$\mathrm{F}_{\text {tab }}=\mathrm{df}$ under level of significance; $\mathrm{F}(\mathrm{v}, \mathrm{v})$ under 5\%; $\mathrm{F}(1,8)$ under $0.05 ; \mathrm{F}_{\text {cal }}=156.1$

Standard valve $=5.32 ;$ Compare $\mathrm{F}_{\text {cal }}$ and $\mathrm{F}_{\text {tab }} ; 156.1 \alpha 5.32$ ' $156.1>5.32$.

\section{Hypothesis II: Decision Rule}

Table 6 shows that, we reject the null hypothesis and therefore accept the alternative hypothesis since Fcal is greater than Ftab, that is $41.4>5.32$ at 0.05 level of significance this means that there is significant relationship between the tax rates and tax avoidance and tax evasion.

Table 6. ANOVA Test statistics.

\begin{tabular}{lcccc}
\hline \multicolumn{1}{c}{ Source } & Ss & Df & Ms & F-ratio \\
\hline Between treatment & 27678 & 1 & 27678 & \\
& & & & 41.4 \\
Within treatment & 5345 & 8 & 668.125 & \\
Total & 33023 & & & \\
\hline
\end{tabular}

$\mathrm{Ftab}=\mathrm{df}$ under level of significance; $\mathrm{F}(\mathrm{v}, \mathrm{v})$ under $5 \% ; \mathrm{F}(1,8)$ under $0.05 ; \mathrm{F}_{\text {cal }} 41.4$;

Standard value $=5.32 ;$ Compare Feat and $\mathrm{F}_{\mathrm{tab}} ; 41.4 \propto 5.32 ; 41.4>5.32$.

\section{Discussion}

From table 1 the study revealed that enlightenment and adequate utilization of tax revenue on public goods will discourage tax avoidance and tax evasion in view of the numbers of respondents that went for strongly agreed. Also in table 2 the study deduced that high tax rate encourages tax avoidance and tax evasion this was justified by the numbers of respondents that went for strongly agree.

Table 3 revealed that personal income tax generation has not being impressive, this was justified by the high number of respondents that went for strongly agree. Table 4 the study revealed that personal income tax rate is too high. From the result of test of hypotheses the study deduced that, there is significant relationship between tax avoidance, tax evasion and the personal income generation in Nigeria, also that there is significant relationship between the tax rates and tax avoidance and tax evasion.

\section{Conclusion}

The study finds out why people evade and avoid taxes and suggested ways of minimizing the practice. The study established a relationship between tax avoidance, tax evasion and the personal income tax generation in Nigeria. It also emphasized on the relationship between tax rates, and tax avoidance and tax evasion. The government should therefore embark upon public enlightenment campaign and adequate utilization of tax revenues on public goods to discourage tax avoidance and tax evasion and also the reduction in tax rate. This will certainly enhance and boost revenue generation in the state as is being pursue with vigour so as to survive in the present day economic meltdown, and inflationary setbacks. For Nigeria Government to meet up with its revenue targets especially now that the services of tax consultants have been discontinued it would be appropriate to take a look at the factors responsible for the incidence of tax evasion and avoidance since a check on these factors will go a long way in reducing if not eradicating the problem. 


\section{Recommendations}

In the light of the above, the following recommendations are made:

1. Nigeria Government should embark upon other means of publicity such as radio messages, television advertisement, post bills as well as the use of town criers to inform taxpayers of changes in tax legislation and need for compliance. Suitable personnel should be recruited and Revenue personnel generally trained and retrained to cope with the demands of the job. Staff should also be motivated through good salary package to insulate them from fraud and other corrupt practices.

2. The tax authority should properly review and evaluate the assessment and collection procedures so as to encourage compliance by the taxpayers. The usual practice of reprinting parts of the tax laws and sending same to the taxpayers expecting that they would understand is not encouraging since these laws are written in legal jargons or terms that are not easily understood. Moreover, tax forms should be made less complex. Vast improvement can be made by improving the design of the forms. Since majority of the people are poor tax evasion becomes inevitable. Government should therefore aggressively tackle the inflationary trend and also ensure that the poor pay very minimal tax.

3. The handling of tax clearance certificates should be well decentralized such that neither the assessor nor the collector can issue tax clearance certificates. The Audit Unit of the Authority should be strengthened to always audit tax remittance by collectors at all levels. This measure will go a long way to curb corrupt practices among tax officials.

4. A legislation compelling banks to inform the tax authorities, on request of any income standing in the account of any taxable person (especially the sellemployed taxpayers) should be put in place by Nigeria government. Nigeria Government should endeavour to provide social amenities to all nooks and crannies of the state' (not just the state capital alone), provide employment opportunities to all by the judicious use of tax proceeds. In this way all will feel belong thereby encouraging voluntary compliance. A census of the taxable population should be conducted throughout the state. This will now update the tax register so that at any given point in time the tax office cart give details of taxable adults and businesses thus reducing the incidence of tax evasion.

\section{References}

Aguolu, O (1999). Taxation and Tax Management in Nigeria, Enugu: Meridian Associates.
Ariwodola, J.A. (1998). Personal income Taxation in Nigeria including Capital Gains Tax, Lagos: JAA Nigeria.

Ayua, LA. (1999). The Nigerian Tax Law, Ibadan: Spectrum Law Publishing.

Ariyo, A. (1997). 'Productivity of the Nigerian Tax System: 1970 - 1990". African Economic Research Consortium (AERC)", Research Paper 67, Nairobi Kenya: AERC. Available from: http://www.aercafrica.org/DOCUMENTS/RP67.PDF. Accessed 28/06/10

Ayodele, 0. (2006). "Tax Policy Reform in Nigeria", World Institute for Developmental Economic Research (WIDER) Research Paper, Vol. 2006/03. Finland: UNIt-WIDER. Retrieved from: http://www.wider.unu.edu/publications/ workingpapers/researchpaperg/2oo6/enGB/2ooo 03/.

Allingham, M. \& Sadmo, A. (1972). Income Tax Evasion: A Theoretical Analysis, Journal of Public Economics, 1,323-338.

Boylan, S. \& Sprinkle, C. (2001). "Experimental Evidence on the Relation between Tax Rates and Compliance": The. Effect of Earned vs. Endowed Income: Journal of the American Taxation Association, 23(1), 75-99.

Balyewu, F.A. (2000). Nigerian Taxation: A Practical Approach, Egbe Kogi: Bhoti International Publishing Ltd.

Collins, J. \& Hussey, R. (2003). "Business Research a practical guide for undergraduate and post graduate students", Ed. New York: Paigrave Macmillan.

Evans, M. R (2009). “Aba Women's Riot (November December 1929)".Blackpast.org. Retrieved from: http://www.blaclcpast.org/?q=gab/aba-womensriots.

Farayole, 0.0. (1987). Guide to Nigerian Taxes, Lagos: All Crowns Nig. Ltd.

Faseun L.A. (2001). "Tax Planning” Lagos Tax the Newsletter of CITN, Lagos: District Society 1(1).

Fisher, R., Coddeeris, J. \& Young, J. (1989). "Participation in Tax Amnesties: The Individual Income Tax": National Tax Journal, 42(2), 15-27.

James, S. \& Nobes, C. (2008). "The Economics of Taxation", 8th ed, Birmingham. Fiscal Publications. Kiabel, D.B. and Nwokah, G N. (2009). "Boosting Revenue Generation by State Governments in Nigeria":

James, S. and Nobes, C. (2009). "Economics for Taxation". 9th ed. Birmingham: Fiscal publications.

Kiabel, B .D. (2001). Personal income Tax ill Nigeria, Owerri: Springfield Publishers.

Lefebvre, M., Pestleau, P., Riedl, A. \& Villeval, M. C. (2011). Tax Evasion, Welfare Fraud, and the Broken Windows Effect: An Experiment in Belgium, France and the Netherlands. LZA Discussion Paper No. 509

Laffer, A. (2009). "Taxes, Depression, and Our Current Troubles". Wall Street Journal, 22" Sept. Eastern Edition. Retrieved from: http://www.proquest.com/.

Muhammed, M.M., Muhanimed, A. (2012). 'Reasons of Tax Avoidance and Tax Evasion': Reflection from Parkistan..

Nigeria (2006). "Tax Assessment Procedure". FIRS Information Circular No: 2006/04, February 2006. Retrieved from: http://www.firs.gov.ng/CMSTemplates/FIRS_S4E/ download ds/Tax_Assessment_Procedure.pdd.

Nigeria (2009). "Capital Gains Tax" Federal Inland Revenue Services. Retrieved from: http://www.firs.gov.ng/capital-gains-tax.aspx.

Nigeria (2009). "Education Tax" Federal Inland Revenue Services Retrieved from: http://www.firs.gov.ng/education-tax.aspx.

Nigeria (2009). "Information Technology Development Levy" Federal Inland Revenue Services. Retrieved from: http :f/www.firs.gov.ng/information-technology-developmehtlevy.aspx.

Nigeria (2009). "Petroleum Profits Tax Act (PPTA)" Federal Inland Revenue Services. Retrieved from: http://www.firs.gov.nglpetroleum-profits-tax.aspx.

Nigeria (2009). “Stamp Duties”, Federal Inland Revenue Services. Retrieved from: http://www.firs.gov.ng/stamp-duties.aspx. 
Nigeria (2009). "Value Added Tax" Federal Inland Revenue Services. Retrieved from: http://www.firs.gov.ng/value-added-tax.aspx.

Nigeria (2009). "Personal Income Tax". Federal Inland Revenue Services (FIRS). Retrieved from: http://www.firs.gov. nglpersonal-income-tax.aspx.

Ogunedele E.A. (1999). Elements of Taxation, Lagos: Libri Services Nig. Ltd.

Onuigbo, 0. (1986). Banking and Finance for Professional, Aba: Yonkee Standard Press Ltd.

Orewa, G.0. (1957). Taxation in Western Nigeria, London: Oxford University Press.

Onyeukwu, H. (2010). "Business Tax in Nigeria: The Controversy of Multiple Taxation" Corporate Governance. Retrieved from: http://works.bepress.com/cgilviewcontent. cgi?article= 1008\&context=humphrey_onyeukwu.

Popoola, N. (2009). “A Good Tax System' 11 Enhance Economic Development". Retrieved from: http://www.puncling.com/ Articl.aspx?theartic=Art200901316544504.

Presidential Committee on National Tax Policy (2008). "Draft Document on the National Tax Policy". Retrieved from http://www.scribd.com/doc/1006373/National-Science-Found ation - fdpopprocappb607

Pommerehne, W., Hart, A. \& Frey, B. (1994). “Tax Morale, Tax Evasion and the Choice of Policy Instruments in Different Political Systems'?: Public Finance, 49, 52-69.
Rynoids, L.G. (1963). Government Finance and Economic Analysis, London: Heiftan Publications.

Sosanya, S.0.A. (1981) Taxation Reform in Nigeria, Lagos: All Crowns Nig. Ltd.

Syndelle, S. (2009). "Taxes - Accountabifity \& Revenue in Nigeria" Nigeria Curiosity.com. Retrieved from:: http://www.nigeriancuriosity.com/2009/11/taxes-accountab ffity-revenue- in-nigeria.html.

Skinner, J. \& Slemrod, J. (1985). “An Economic Perspective on Tax Evasion'": National Tax Journal, 38, 345-353.

Srinivasan, T. (1973). “Tax Evasion"': A Model Journal of Public Economics, 2(3), 339-346.

Toby, R. (1983) The Theory and Practice of income Tax, Lagos: Macmifian Press Ltd.

Uadiale, O.M., Fagbemi, T.O. \& Ogtmleye, J.O. (2010). "An Empirical Study of the Relationship between Culture and Personal income Tax Evasion in Nigeria': European Journal of Economics, Finance and Administrative Sciences, 20,116126.

Warner, S. (1965). "Randomized response: a survey technique for eliminating evasive answer bias": Journal of the American Statistical Association, 60 ,63-69.

Worldwide Legal Directories. Retrieved from: http://www.hg.org/article.asp?id=5944. 